\title{
Erratum to: Mayarhynchus karlae n. g., n. sp. (Acanthocephala: Neoechinorhynchidae), a parasite of cichlids (Perciformes: Cichlidae) in southeastern Mexico, with comments on the paraphyly of Neoechinorhynchus Stiles \& Hassall, 1905
}

\author{
Carlos D. Pinacho-Pinacho · Jesús S. Hernández-Orts • Ana L. Sereno-Uribe • \\ Gerardo Pérez-Ponce de León • Martín García-Varela
}

Published online: 28 July 2017

(C) Springer Science+Business Media B.V. 2017

Erratum to: Syst Parasitol (2017) 94:351-365

DOI 10.1007/s11230-017-9704-x

In the original publication of the article, the name Neoechinorhynchus was mis-spelled (as Neoechynorhynchus) in the title, abstract and discussion.
The authors would like to apologize for any inconvenience caused.

The online version of the original article can be found under doi:10.1007/s11230-017-9704-x.

C. D. Pinacho-Pinacho ( $\square)$

Universidad de la Sierra Sur, División de Estudios de Postgrado, Ciudad Universitaria, Guillermo Rojas

Mijangos S/N, Miahuatlán de Porfirio Díaz,

C. P. 70800 Oaxaca, Mexico

e-mail: carlos.pinacho@unsis.edu.mx

J. S. Hernández-Orts

Instituto de Biología Marina y Pesquera Almirante Storni, Consejo Nacional de Investigaciones Científicas y

Técnicas (CONICET) y Escuela Superior de Ciencias

Marinas (ESCiMar), Universidad Nacional del Comahue,

Güemes 1030, 8520 San Antonio Oeste, Río Negro,

Argentina

A. L. Sereno-Uribe · G. Pérez-Ponce de León ·

M. García-Varela

Laboratorio de Helmintología, Instituto de Biología,

Universidad Nacional Autónoma de México, Ap. Postal

70-153, Ciudad Universitaria,

C. P. 04510 Ciudad de México, Mexico 